\title{
New SHRIMP ages for Ladakh and Karakoram Batholiths - inherited zircons indicate involvement of older crust
}

\author{
T Ahmad $^{1 *}$, L White ${ }^{2}$, M Forster ${ }^{2}$, T R Ireland ${ }^{2}$ and G Lister ${ }^{2}$ \\ 1 Department of Geology, University of Delhi, Delhi, INDIA \\ 2 Research School of Earth Sciences, The Australian National University, Canberra, AUSTRALIA \\ * For correspondence, email: tahmad100@yahoo.co.in
}

We report new U-Pb zircon SHRIMP ages for the Ladakh and Karakoram batholiths. The samples of the Ladakh Batholith were collected from the Khardung La and Chang La tops and those of the Karakoram Batholith were collected along the Tangtse gorge and Darbuk-Shyok section.

Separated zircon crystals display zoned zircon crystals typically observed in igneous rocks. The age obtained for the Khardung La and Chang La top samples is circa $58 \mathrm{Ma}$. These ages are similar to the age data published by earlier workers, confirming a strong phase of magmatism in the Ladakh Batholith at approximately $58 \mathrm{Ma}$. No inherited older zircons were observed in these samples, confirming the observations of earlier studies.

A Karakoram Batholith sample was collected near Tangste Gompa. This sample is a coarse grained porphyritic granite and gave an age of circa $32 \mathrm{Ma}$. One zircon grain from this sample gave a late Permian age, and this may indicate the involvement of older crust in the batholith.

Muscovite-biotite-garnet bearing leucocratic granite dykes are best exposed in the Tangtse gorge where many leucocratic granitic dykes dissect each other (Figures 1 and 2). One sample was collected from near the middle of the gorge between the northern and southern strands of the Karakoram fault. This sample gave an age of circa $18 \mathrm{Ma}$.

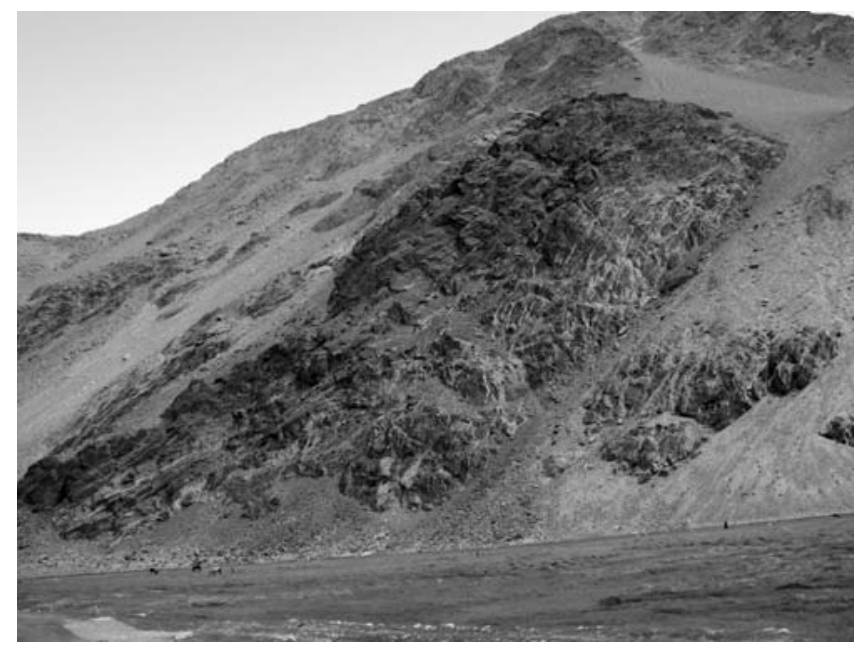

FIGURE 1. Leucocratic granitic dykes, Tangtse gorge
This is consistent with earlier published age data that was associated with movement on the Karakoram fault.

Another sample of the Karakoram Batholith was collected further to the north, near the Karakoram fault. This sample has gneissic characteristics and is richer in mafic phases (biotitehornblende). The age of this sample is circa $102 \mathrm{Ma}$. This age is consistent with data published by earlier workers indicating that there was also a major magmatic phase in the Karakoram Batholith at around $102 \mathrm{Ma}$.

One leucocratic granitic dyke sheet sampled between Darbuk and Shyok villages has a mixture zircon crystals that gave a range of ages. Some of these zircon grains are possibly inherited. These range of ages found in these samples range between $15 \mathrm{Ma}$ and $97 \mathrm{Ma}$. All of these dates have been reported from at least one of the other sampled localities by various methods. Interestingly several grains gave ages that have not been previously reported (ranging between 250 - $970 \mathrm{Ma}$ ). These older ages may indicate that older crust was involved in the generation of part of the Karakoram Batholith (possibly the southern portion of the Tibetan slab?). Recent suggestions that collision was as late as $35 \mathrm{Ma}$ may need more consideration in the light of magmatic zircon ages of 32-36 Ma.

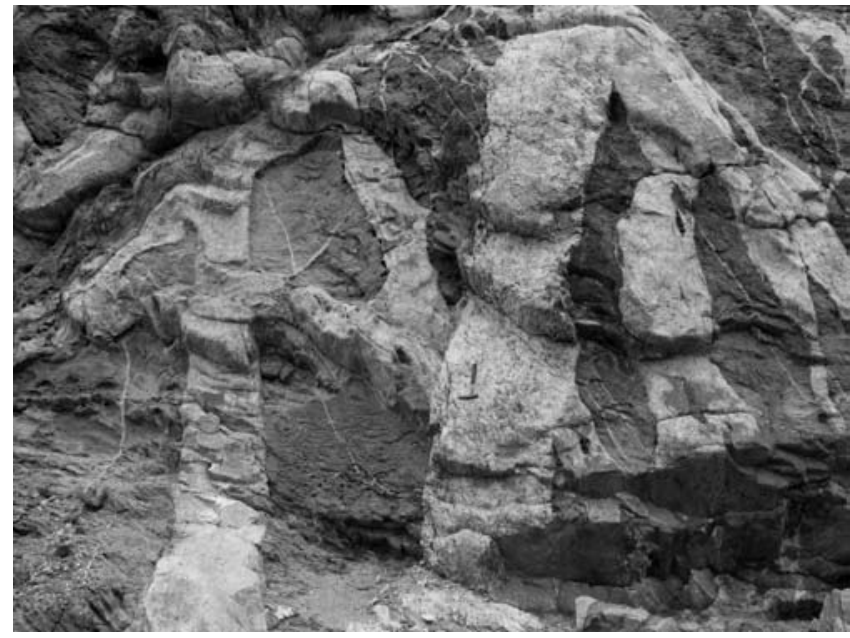

FIGURE 2. Close up of Figure 1 